\begin{tabular}{|l|c|c|c|r|}
\hline $\begin{array}{l}\text { Cuadernos de Investigación Geográfica } \\
\text { Geographical Research Letters }\end{array}$ & 2018 & N $^{\circ} 44(2)$ & pp. 659-673 & $\begin{array}{r}\text { ISSN 0211-6820 } \\
\text { eISSN 1697-9540 }\end{array}$ \\
\hline
\end{tabular}

\title{
MOISTURE TRANSPORT FROM THE ARCTIC: A CHARACTERIZATION FROM A LAGRANGIAN PERSPECTIVE
}

\author{
M. VÁZQUEZ ${ }^{1 *}$, R. NIETO $^{1,2}$, A. DRUMOND ${ }^{1}$, L. GIMENO $^{1}$ \\ ${ }^{1}$ Environmental Physics Laboratory (EPhysLab), Facultade de Ciencias, \\ Universidad de Vigo, Ourense, Spain. \\ ${ }^{2}$ Department of Atmospheric Sciences, Institute of Astronomy, Geophysics and Atmospheric Sciences, \\ University of São Paulo, São Paulo, Brazil.
}

\begin{abstract}
The Arctic Ocean has suffered extreme reductions in sea ice in recent decades, and these observed changes suggest implications in terms of moisture transport. The Arctic region is a net sink of moisture in terms of the total hydrological cycle, however, its role as a moisture source for specific regions has not been extensively studied. Our results show that $80 \%$ of the moisture supply from the Arctic contributes to precipitation over itself, representing about $8 \%$ of the global moisture supply to the Arctic, the remaining $20 \%$ is distributed in the surrounding. A reduction in the sea ice extent could make the Arctic Ocean a slightly higher source of moisture to itself or to the surrounding areas. The analysis of the areas affected by Arctic moisture transport is important for establishing those areas vulnerable to change in a framework of a growing sea ice decline. To this end, the Lagrangian model FLEXPART was used in this work to establish the main sinks for the Arctic Ocean, focusing on the moisture transport from this region. The results suggest that most of the moisture loss occurs locally over the Arctic Ocean itself, especially in summer. Some moisture contribution from the Arctic Ocean to continental areas in North America and Eurasia is also noted in autumn and winter especially from Central Arctic, the East Siberian Sea, the Laptev, Kara, Barents, East Greenland and Bering Seas, and the Sea of Okhotsk.
\end{abstract}

Transporte de humedad desde el Ártico: una caracterización desde una perspectiva Lagrangiana

RESUMEN. En las últimas décadas el océano Ártico ha sufrido un importante retroceso en el hielo marino, pudiendo estar estos cambios relacionados con variaciones en el transporte de humedad. La región ártica es un sumidero neto de humedad en términos de ciclo hidrológico total, sin embargo, su rol como fuente de humedad en algunas regiones concretas todavía no ha sido extensamente investigado. Nuestros resultados muestran que el $80 \%$ de la contribución de humedad ártica contribuye a precipitación sobre la propia región, representando este valor aproximadamente el $8 \%$ del aporte de humedad global sobre el Ártico. El $20 \%$ de humedad restante se distribuye en las regiones circundantes. El 
análisis de las áreas afectadas por el transporte de humedad desde el Ártico resulta importante a la hora de establecer aquellas áreas más vulnerables al cambio en el marco de un creciente retroceso en el hielo marino. Para tal fin, se ha empleado el modelo lagrangiano FLEXPART para establecer los principales sumideros para el océano Ártico, centrándose en el transporte de humedad desde esta región. Los resultados sugieren que la mayor parte de la humedad tiene lugar sobre el propio Ártico, especialmente en verano. Sobre Norte América y Eurasia se observa algún aporte de humedad en otoño e invierno, especialmente desde el Ártico Central, el mar de Siberia Oriental, los mares de Laptev, Kara, Barents, Groenlandia oriental y Bering y el mar de Okhotsk.

Key words: Arctic sinks, moisture transport, Lagrangian model.

Palabras clave: sumideros árticos, transporte de humedad, modelo lagrangiano.

Received: 14 November 2017

Accepted: 7 December 2017

*Corresponding author: Marta Vázquez, Environmental Physics Laboratory (EPhysLab), Facultade de Ciencias, Universidad de Vigo, Ourense, Spain. E-mail address: martavazquez@ uvigo.es

\section{Introduction}

The Arctic region is currently experiencing extreme changes. The extent of sea ice has shown a downward trend in the last few decades for all seasons (Cavaliery and Parkinson, 2012; Polyakov et al., 2012; Comiso and Hall, 2014; Comiso et al., 2008; Parkinson and DiGirolamo, 2016), reaching its lowest recorded September value in 2012 according to the satellite record (Fetterer et al., 2016). Moreover, the melt season is lengthening (Stroeve et al., 2014), producing even longer periods without any sea ice at all over some regions. This situation is expected to increase under global warming (Holland et al., 2006; Wang and Overland, 2009; Overland et al., 2013).

This reduction in sea ice and its possible implications have been the subject of wide-ranging investigations in recent years. The effects of sea ice decline on the climate system have been of particular interest, and a detailed review of its local and remote effects was undertaken by Vihma (2014). Any reduction in sea ice has a direct influence on moisture uptake, and increased evaporation over the region has already been found for the period 2003-2013 (Boisvert et al., 2015). Many previous authors have analysed the effect of decreasing sea ice on atmospheric circulation. Overland and Wang (2010) for example showed the influence of sea ice loss on patterns of atmospheric circulation. Furthermore, despite it is a subject under discussion, reduced sea ice has been suggested to affect mid-latitude weather for several authors. Recent results point to a link between sea ice reduction and extreme winter weather conditions in some Northern Hemisphere mid-latitudes regions (Wegmann et al., 2015; Cohen et al., 2014; Liu et al., 2012). Moreover, a number of authors have 
highlighted a relationship between the decrease in sea ice and an increase in winter snowfall over Eurasia (Wegmann et al., 2015; Liu et al., 2012; Park et al., 2012), but with the opposite relationship applying over North America, and in general at the hemispheric scale (Park et al., 2012). So, there is a lack of consensus today on the link sea ice reduction- extreme winter weather depending on the analyzed region and much of the methods used to analyze the linkages.

Several studies have analysed the moisture budget for the Arctic region (e.g. Groves and Francis, 2002; Serreze et al., 2006). From these studies, the Arctic region can be considered a net sink of moisture being specifically dependent on the moisture input by precipitation from lower latitudes (Serreze et al., 2006). Despite this fact, and as commented before, the recent changes suffered on the Arctic and the intensification on the hydrological cycle in this region could have influences beyond the Arctic as well (e.g. Cohen et al., 2014; Vihma 2014). As far as we know, no complete analysis of moisture transport from the Arctic has yet been undertaken. Due to the recent increase in the amount of open water in the Arctic Ocean, it is of crucial importance to analyse how this change can affect the moisture transport from the region. This analysis allows the identification of those areas affected by the Arctic contribution of moisture and the establishment of those regions most vulnerable to possible changes in moisture transported from the Arctic. For this purpose, the Lagrangian model FLEXPART was used in this study to establish the main sinks for moisture originating in the Arctic Ocean. Lagrangian models have previously been shown to be useful for investigating source-sink relationships (Gimeno et al., 2012), and have been widely applied to this end in a number of previous studies (e.g., Nieto et al., 2007; Sodemann, 2008; Vázquez et al., 2016).

\section{Methods}

The Arctic Ocean was divided into 15 different areas as shown in Figure 1. This division follows the approach of Boisvert et al. (2015) in separating the Arctic Ocean into its more relevant areas. Despite the division of the Arctic Ocean can be realized in different ways, this division was chosen because it allows the analysis of the main Arctic Seas separately and it includes most of the sea ice covered areas (Parkinson et al., 1999; Parkinson and Cavalieri, 2008). These 15 sub-areas are considered in this work as "source" regions. It is important to notice that the use of the term "source" is referred here to those regions from where particles were followed.

A Lagrangian approach was used to analyse moisture transport from the Arctic, based on the particle dispersion model FLEXPART v9.0 (i.e., the FLEXible PARTicle dispersion model of Stohl and James $(2004,2005)$ ) and forced by ERA-Interim reanalysis data from the European Centre for Medium-Range Weather Forecasts (ECMWF). Data from this reanalysis cover the period from January 1979 and continue to be used, extending forwards in near-real time (Dee et al., 2011). The data are available at six-hour intervals at a $1^{\circ} \times 1^{\circ}$ spatial resolution in latitude and longitude on 61 vertical levels (1000 to $0.1 \mathrm{hPa}$ ). 


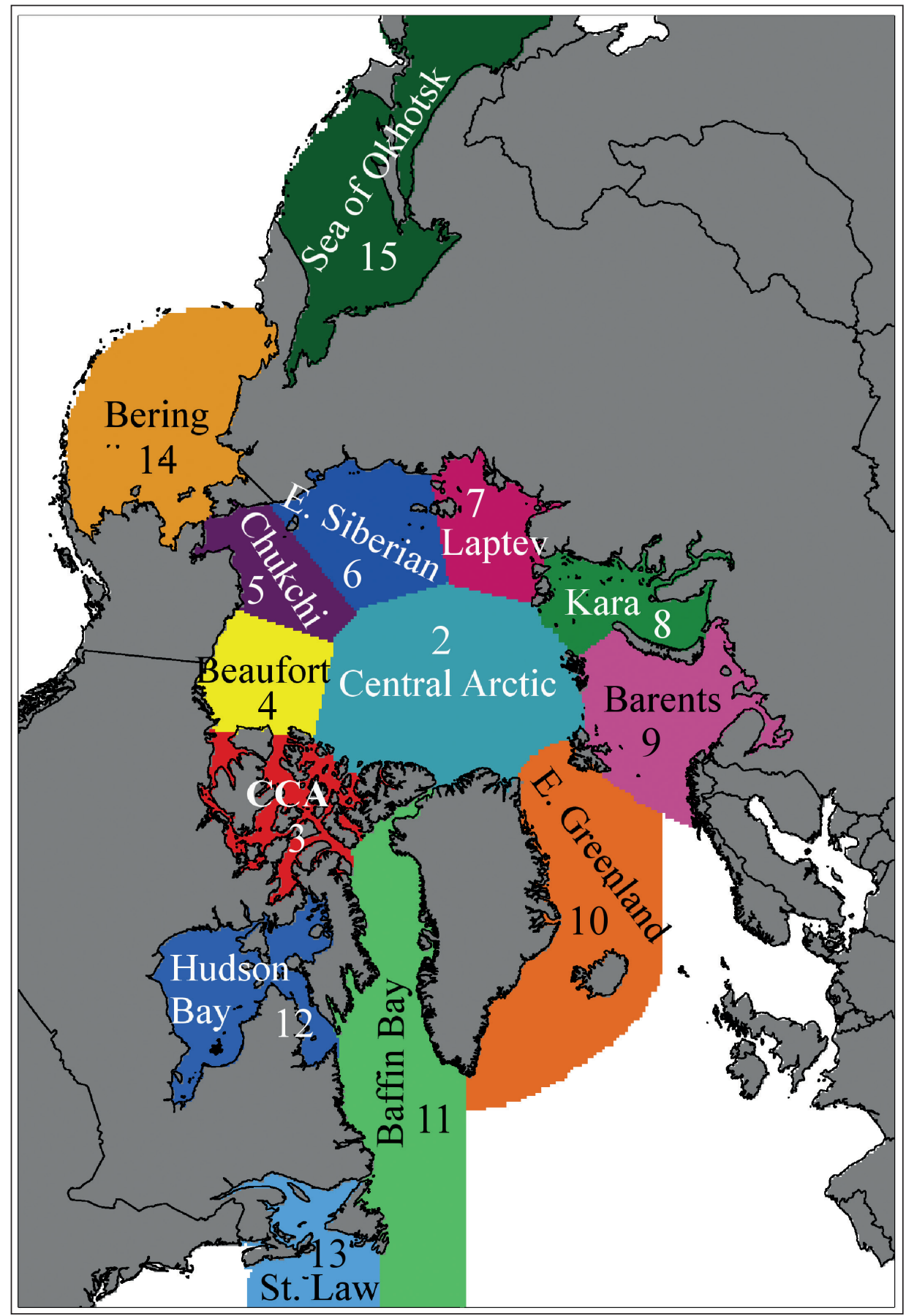

Figure 1. Division of the Arctic as used in this study following Boisvert et al.(2015). 
The FLEXPART is a powerful tool model to conduct Lagrangian analysis that divides the global atmosphere into finite elements of volume ( 2 million in our experiment) with equal mass (hereafter "particles") and, it follows the air movement by tracking individual 3-D trajectories backward in time every 3 hours. These modeled trajectories allow identifying the main sinks of moisture or the main sources for a specific region in the world by analysing changes in specific humidity $(q)$ in a forward or backward mode, respectively. Taking into account the changes in $(q)$ it is possible to obtain the net rate of change of water vapour $(e-p)$ for every particle (of constant mass $m$ ) along its trajectory using the expression $(e-p)=m(d q / d t)$, where $e$ and $p$ represent evaporation and precipitation, respectively. The model assumes that the particles do not interact with the surrounding parcels of air. The total atmospheric moisture budget $(E-P)$ is obtained by adding up $(e-p)$ for all the particles over a given area at each time step. It is important to clarify that the $(E-P)$ value, as calculated here, do not represent the total $(E-P)$ balance over any specific region and cannot be compared with results obtained via a eulerian perspective. In our approach, the $(E-P)$ values represent only the moisture change of those particles that come from the Arctic region. For further details on Lagrangian methodologies, and their comparison with another ones, for moisture transport analysis can be found on Gimeno et al. (2012).

In this work, the methodology established by Stohl and James $(2004,2005)$ were used in order to analyse the transport of moisture from the Arctic region (and subareas) and to investigate the areas of major moisture supply (sink regions, identified as those where $\mathrm{E}-\mathrm{P}<0$ ). For this purpose, all the particles over the Arctic region (as a whole and for individual areas) were forward followed during 10 days, the commonly used period as the average residence time of water vapour in the atmosphere (Numaguti, 1999). The amount of particles considered for the computation is dependent on the area selected, being approximately 100000 for the complete Arctic Ocean initially well mixed horizontally and vertically at any time (Stohl and James, 2004).

Despite being a useful tool on moisture transport analyses and to be widely used for this purpose (e.g. Stohl et al., 2008; Nieto et al., 2007; Gimeno et al., 2013), FLEXPART model has some limitations. The limited resolution of input data, as well as their uncertainties and interpolation, is an important source of error, especially in areas of low data coverage (Schlosser et al., 2008; Scharchilli et al., 2011). Stohl et al. (2001) suggest typical average errors of approximately $20 \%$ of the travel distance and accordingly to Bowman et al. (2012) globally averaged error of around $350 \mathrm{~km}$ can be found in lagrangian methodologies considering 6-h wind sampling for 5 days forward trajectories. These errors are mainly associated with the temporal resolution of input data (Bowman et al., 2013). Moreover, there are numerical errors related with the temporal variation of the particles' moisture, which produces miscalculation on the moisture transport (Stohl and James, 2004), and important uncertainties can be found if the method does not properly close the water cycle Gimeno et al. (2012).

In this study, we consider the 36-year period 1980-2015 for the tracking of particles from the Arctic Ocean as a whole and from the individual regions described previously. Because the tracking is undertaken for 10 days, the moisture budget $(E-P)$ over each grid cell was integrated for the whole period and hereinafter denoted as $(E-P) i 10$, this amount showing those areas where particles acquire or lose moisture along their trajectories. The aim of this 
work is to analyze the moisture transport from the Artic region, and for that purpose, the particles from the ocean were followed along their trajectories. As we are interested in those areas with a net moisture contribution from the Arctic, only those regions showing negative values of $(E-P) i 10$ were selected (Castillo et al., 2014). Despite the model take into account moisture changes of particles along its trajectories from the Arctic, at the initial step of the simulation, all the moisture availability is considered; some of which should proceed from external areas. However, from this time and forward, only the processes over the trajectories are considered.

In order to analyze the amount of moisture provided by the Arctic Ocean compared with the total global amount, the global forward experiment is also considered in this work. The contribution to precipitation $((E-P) i 10<0$ values $)$ calculated by tracking the trajectories from the complete world for 10 days was calculated for the period 1980-2015 and added over the complete Arctic Ocean. Considering this value as the total moisture contribution, the percentage of contribution over the complete Arctic Ocean is calculated seasonally for every one of the regions that form the area of study.

\section{Results}

The analysis described above allowed us to identify sinks for the moisture from the Arctic Ocean. Figure 2 represents the moisture contribution $((E-P) i 10<0$ values $)$ from the whole of the Arctic Ocean (all the regions in Figure 1 taken together) on an annual and seasonal basis over its sinks (blueish colors in Figs. 2a and 2b-e, respectively). In general, it can be observed that most of the moisture contribution from the Arctic Ocean occurs over the region itself, especially over the Central Arctic and East Greenland Seas, with the contribution over the Gulf of Alaska and the western coast of Greenland also notable. An important moisture contribution occurs over the Eurasian seas (from Barents to the Chukchi Sea), the Beaufort Sea, and the Sea of Okhotsk. However only the $20 \%$ of the Arctic moisture is exported outside, remaining the $80 \%$ on the Arctic Ocean itself. In seasonal terms, the spatial distribution of moisture contribution shows some variations. In spring (Fig. 2b), a major contribution can be seen over the East Greenland Sea, on the southeastern coast of Greenland, and also over the Gulf of Alaska where an important contribution can be seen. Over the Central Arctic, and especially over its surrounding seas, the moisture contribution shows lower values than the annual mean. In general, the contribution in spring is seen over oceanic areas, although some contribution occurs over northeastern Russia, the west coast of North America, and northern Canada (values lower than $0.8 \mathrm{~mm} /$ day). In summer (Fig. 2c) the moisture contribution increases considerably and is especially important over the Central Arctic, the East Greenland Sea, and Baffin Bay, although some high values (greater than $4.8 \mathrm{~mm} /$ day) appear over most of the Arctic Ocean. A generally less important contribution occurs over continental areas during summer. In autumn (Fig. 2d) the moisture contribution from the Arctic Ocean shows a similar distribution to the annual mean. The contribution occurs in general over the whole Arctic Ocean, with the exception of the Bering Sea and most of the Norwegian and Barents Seas. Maximum moisture contribution is observed over the Central Arctic, the East Greenland Sea, the West Coast of Greenland, the Norwegian coast, and the Gulf of Alaska. During this season the moisture contribution is increased over the continental areas, especially over North Eurasia, North America, and Canada. Finally, in 
winter (Fig. 2e) the moisture contribution is more evenly distributed, affecting the oceanic areas in general, but also revealing some contribution over the continents of North America and northern Asia. The most important contribution occurs over the East Greenland Sea, the Gulf of Alaska, and the Norwegian coast.

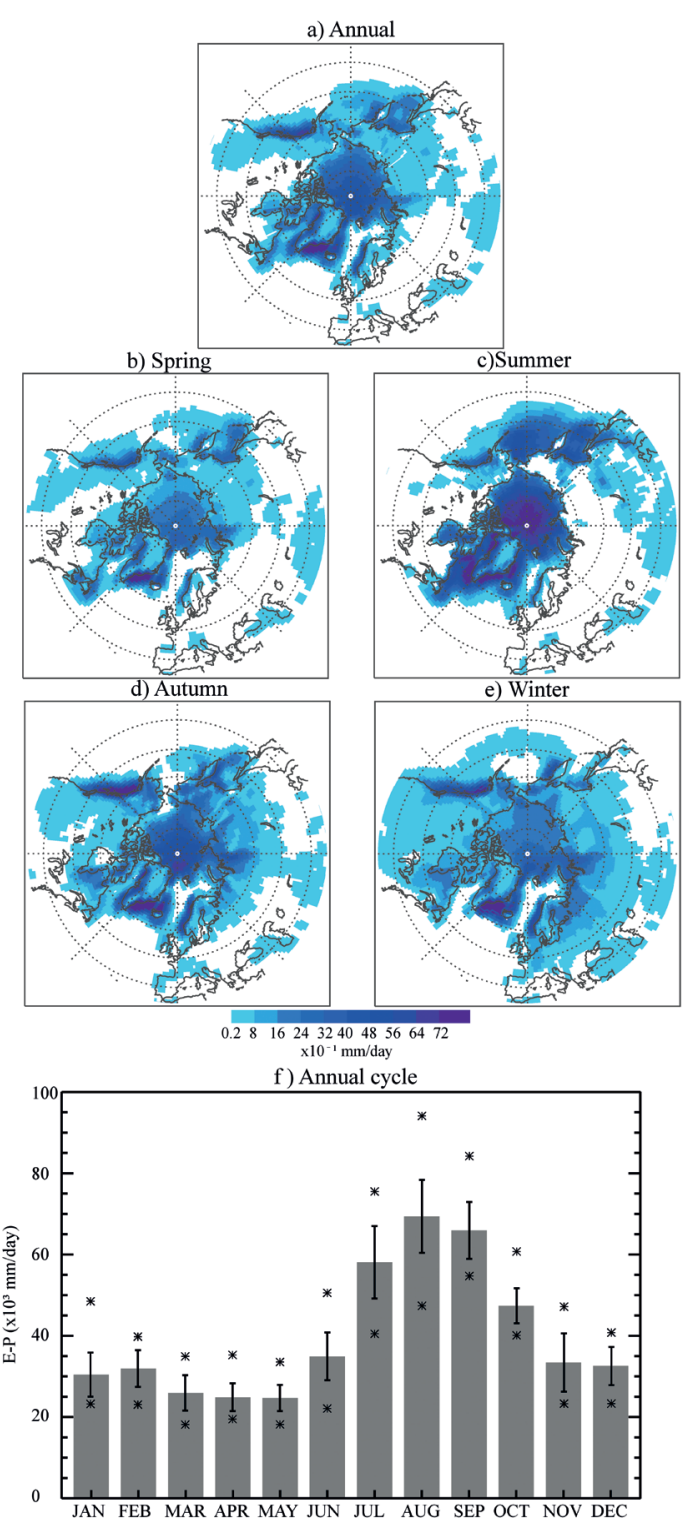

Figure 2. Geographical (E-P)il0<0 distribution from the whole Arctic Ocean annually (a) and seasonally ( $b-e)$, and seasonal cycle(f) calculated by adding the moisture supply at every grid point for the complete region and for each month. Asterisks represent maximum and minimum values for each month and vertical whiskers represent the standard deviation. 
In order to show the annual variability of the moisture supplied by the whole Arctic Ocean, Figure $2 \mathrm{f}$ shows the monthly contributions. It can be seen that these are at their highest levels from June to October, with a maximum contribution in August, followed by September. For the remaining months, the contribution does not show important variations. As expected, this seasonal cycle seems to be influenced by the extent of the sea ice as the Figure 3 shows for four regions of our area of study: the Arctic Ocean, Canadian Archipelago, Barents and Bering Seas. Therefore, under lower values of sea ice extent, the sources supply more moisture to their sinks. In this figure red lines represent the sea ice extent over the specific region (calculated from Sea ice concentration data obtained from the NASA Goddard-merged parameter in the NOAA/NSIDC Climate Data Record (CDR) product (Meier et al., 2013)) and blue lines represent the moisture contribution $((E-P) i 10<0$ values $)$ over the sink calculated from each source. Minimum values on sea ice extent appear in late summer and early autumn (Cavalieri and Parkinson, 2012), providing a greater amount of moisture available for precipitation during these seasons.

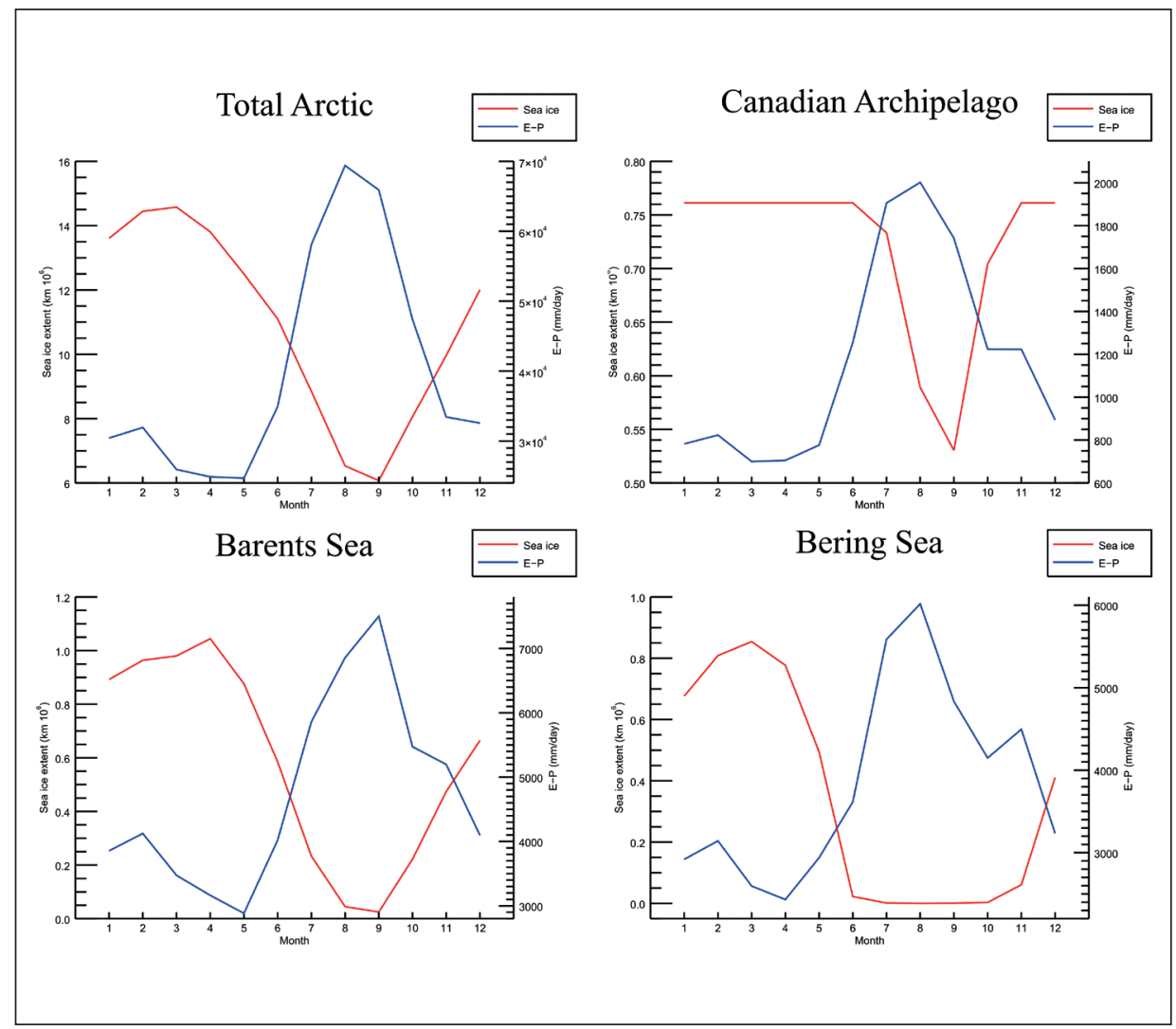

Figure 3. Annual cycle for sea ice extent, represented by red lines, and moisture contribution (E-P) il0<0 values), represented by blue lines, for the total Arctic Ocean, Canadian archipelago, the Barents Sea, and the Bering Sea. Data for sea ice extent obtained from the NASA Goddardmerged parameter in the NOAA/NSIDC Climate Data Record (CDR) product. 
In order to assess the moisture contributions from the different parts of the Arctic Ocean, Figure 4 shows the values of $(E-P) i 10<0$ for each area indicated in Figure 1. In general, in each case the maximum contribution occur over the area itself, especially for the Central Arctic and the surrounding seas (regions 2 to 9). The exceptions are the Barents Sea and Baffin Bay, which, despite they provide some moisture over themselves, show their maximum moisture contribution over the regions around them. For the Barents Sea, its contribution affects mainly the Central Arctic to the north of the source, the Kara Sea, the East Greenland Sea, and the Norwegian coast. The moisture contribution from Baffin Bay mainly affects the surrounding coastal areas and to a lesser degree the East Greenland Sea and the Norwegian coast, the Canadian Archipelago, Hudson Bay, and the Gulf of Alaska. Both these regions were previously identified as moisture sources for the Arctic: Baffin Bay represents an important moisture source for the Canadian Archipelago (Koerner and Russel, 1979) and for the Greenland ice sheet affecting its melt onset (Stroeve et al., 2017). The Barents Sea was recently discovered to provide a significant amount of moisture for the Arctic system in winter (Vázquez et al., 2016). These previous publications suggest that these regions could be considered evaporative areas for moisture entering the Arctic domain, which could explain the lower values in moisture contribution observed over them. For the remaining regions, the Canadian seas (the Canadian Archipelago, and the Beaufort and Chukchi Seas) provide some moisture contribution for the Gulf of Alaska, and the Eurasian seas show some influence over northern Russia, especially the East Siberian Sea. For those areas situated at lower latitudes (East Greenland, Baffin Bay, Hudson Bay, St. Lawrence, Bering Sea and the Sea of Okhotsk), the moisture contributions are more widespread. The East Greenland Sea mainly provides moisture for the oceanic regions around Greenland, and some contribution can also be observed over Hudson Bay and the Gulf of Alaska. The contribution of Hudson Bay is similar to that of Baffin Bay, but it has less of an influence over the East Greenland Sea and the Norwegian Coast. The St. Law contribution mainly affects the south of Greenland. The Bering Sea provides moisture over and around itself, affecting mainly the Chukchi, East Siberian and Laptev Seas, the Gulf of Alaska, and the Sea of Okhotsk. The moisture contribution from this last sea, the Sea of Okhotsk, affects north Pacific oceanic areas and some continental regions over Eastern and Central Russia.

The complete analysis of all the regions that constitute the Arctic Sea is plotted in Figures S1 to S14 (See Supplementary materials at http://publicaciones.unirioja.es/ revistas/cig2018/Vazquez_supplmat.pdf). These figures show the seasonal moisture contribution of each, together with the annual cycle (as Figs 2b-f). In general terms, it is possible to see that the maximum moisture contribution occurs from July to September and the minimum from March to May for all regions (panel b in each Fig. S1-S14). Spring represents not only the season with the lowest contribution (panel b) but also with the lowest spatial distribution (panel a). Despite the highest contribution being in summer or autumn, in general, the greatest geographical spread occurs in autumn and/or winter, the exception being the Beaufort and Chukchi Seas (Figs. S4a and S5a). For both these sources, the moisture contribution in summer shows not only the highest values, it also affects the greatest area due to the increase in moisture contribution over the Bering 
Sea. Some regions show an increase in moisture contribution over Eurasia in autumn and winter, including the Central Arctic (Fig. S2a), Baffin Bay (Fig. S10a), East Siberian (Fig. S5a), Laptev (Fig. S6a), Kara (Fig. S7a), Barents (Fig. S8a) and East Greenland Seas (Fig. S9a). This increase can be observed in autumn for the Beaufort (Fig. S3a) and Chukchi (Fig. S4a) Seas, and in summer and autumn for the Bering Sea (Fig. S13a) and the Sea of Okhotsk (Fig. S14a).

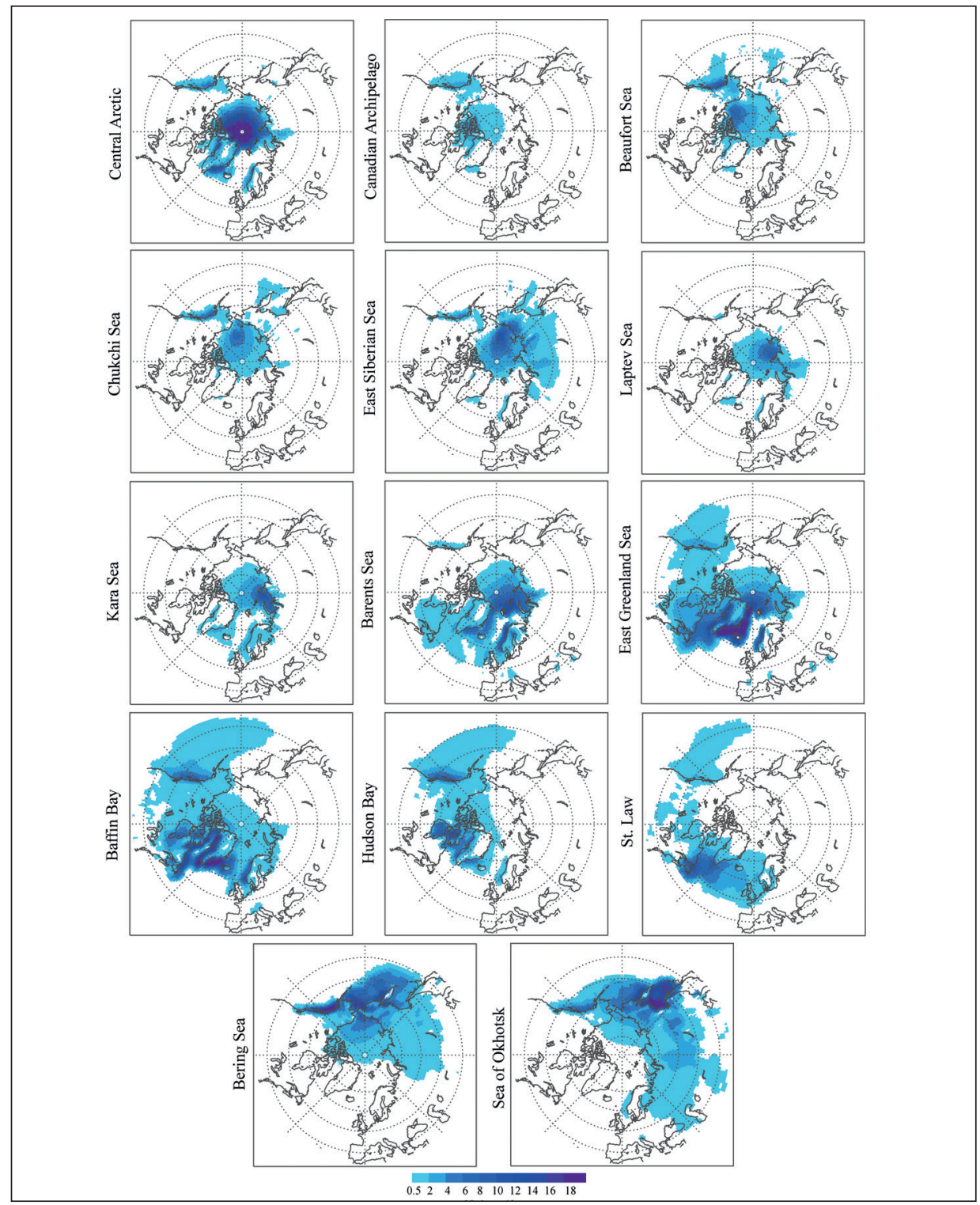

Figure 4. Geographical distribution of $(E-P) i 10<0$ analysed annually from each of the source areas described in Figure 1. 
It has been emphasized that although the Arctic Ocean (and its sub-areas is a net sink of moisture in a climatological global flux balance, it may also act as a source of moisture. In order to provide more context on the Arctic moisture contribution over its sinks, Figure 5 shows the percentage of the moisture contribution from each Arctic region over the complete Arctic Ocean itself. Those results were calculated taking into account the total moisture supply from the entire world (a forward running with FLEXPART was done for all the particles distributed in the complete atmosphere) over the whole Arctic Ocean (as considered in this work). Therefore, the moisture supply from the Arctic Ocean over itself represents approximately the $8 \%$ of the global moisture supply that comes from the rest of the Earth, being the Central Arctic (region 2), Barents Sea (9) and Greenland Sea (10) the regions that provide the major amount of moisture. Despite lower seasonal variation (lower than $1.5 \%$ for the total contribution), the percentage slightly increases in summer, and it is minimum in spring.

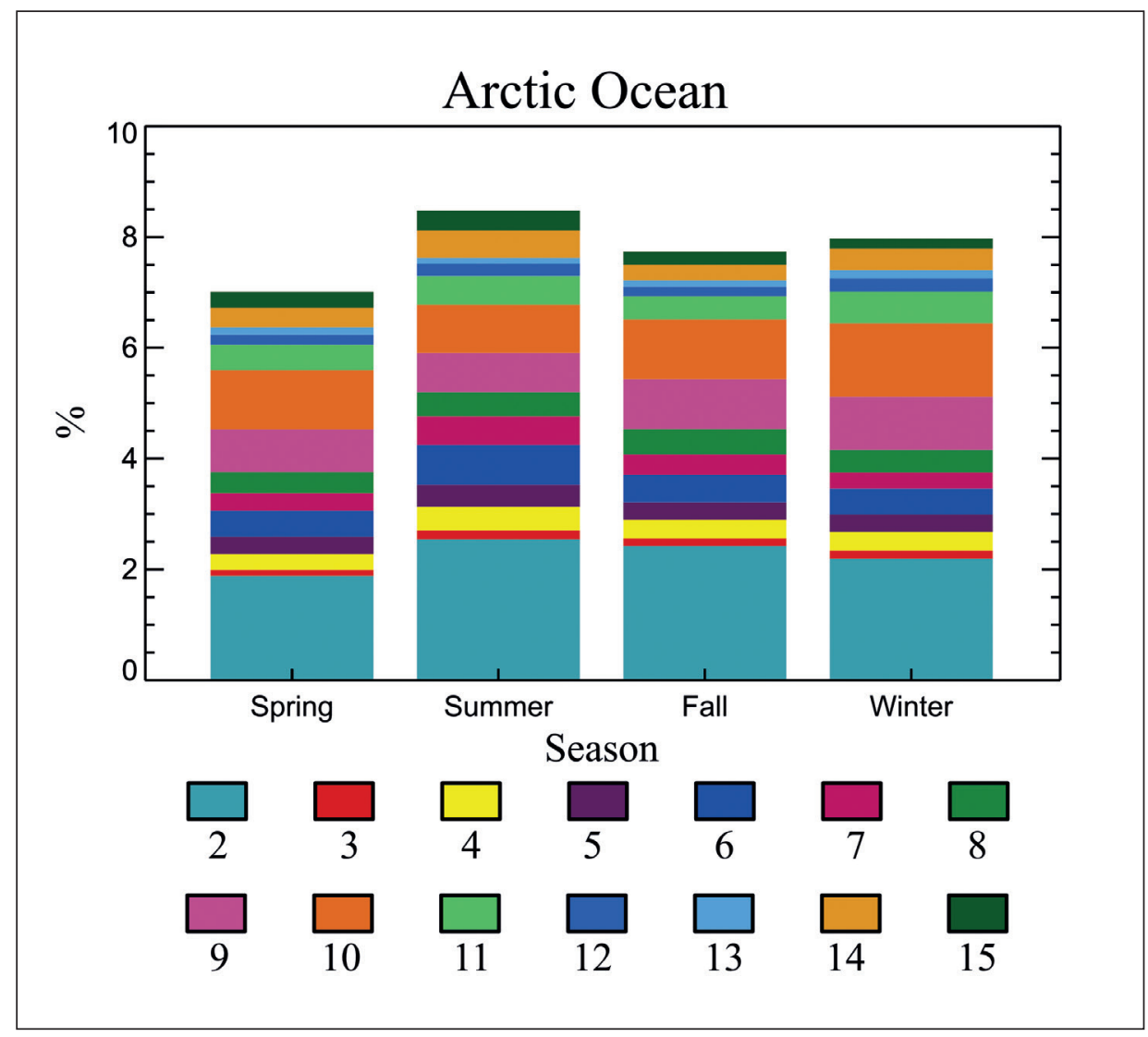

Figure 5. Percent of moisture supply $(E-P) i 10<0$ values) over the total ocean, from every source area, referred to the total global supply. Ciolours and numbers represent the source areas as defined in Figure 1. Total global supply was calculated analysing forward trajectories for 10 days from oceanic and terrestrial regions for the complete globe. The moisture contribution is calculated only over the Arctic Ocean. 


\section{Discussion}

In general, it was observed that the Arctic moisture mainly remains over the region itself, being the contribution higher over oceanic areas and lower over continental ones. Despite almost the complete Arctic Ocean show some moisture contribution, the Norwegian Sea shows values close to zero. This region was previously found as an important evaporative area (Jakobson and Vihma, 2009) and even was found to be a moisture source for the Arctic Ocean (Vázquez et al., 2016). These findings agree with our results, as the evaporation over the sea would result in lower values in the moisture contribution (calculated here as $(E-P) i 10<0$ values).

The moisture transport from the Arctic as studied here shows some differences according to the regions and seasons. The moisture contribution shows higher values on summer, coinciding with the lowest sea ice extent. Some previous studies have suggested a maximum of precipitation over the Arctic region on summer months (e.g. Jakobson and Vihma, 2009), however, this fact does not seem to be only linked with sea ice decline, but also with the poleward moisture transport (Vázquez et al., 2016; Sorteberg and Walsh, 2008). On winter and autumn, the moisture contribution from the Arctic region shows lower values. However, for these months some moisture contribution appears affecting continental areas, especially over northern Eurasia. This result is in agreement with previous publications that suggest an influence from the Arctic over Eurasia (Liu et al., 2012; Wegmann et al., 2015). Wegmann et al. (2015) have suggested a relation between the increased moisture evaporation over Barents and Kara Sea and higher snow precipitation over Siberia in autumn. Despite from our results such relation cannot be addressed, some moisture contribution can be found from these seas (Figs. S7 and S8).

The present work constitutes the first attempt in order to analyze the moisture transport from the Arctic Ocean, not only for the complete region but also for the individual regions. Despite the methodology employed here was previously used for similar purposes (eg. Stohl et al., 2008; Nieto et al., 2007), it has several limitations as listed previously. One of the most important limitations on analyzing the Arctic region is the lack of observation available to validation. Most of the Arctic information is provided by remote sensing sources and despite recent efforts were realized in order to obtain in situ measurement (e.g. Lopez-Moreno et al., 2016), the characteristics of the region difficult this kind of products.

\section{Conclusions}

Characterization of the moisture contribution from the Arctic region was performed using a Lagrangian approach for the period 1980- 2015.

In general, the moisture contribution from the Arctic occurs over the region itself, taking into account both the complete Arctic and its more relevant individual areas. Despite this local contribution, some influence on the surrounding areas was found on our results, affecting mainly North America and Eurasia during fall and winter, mainly from the central Arctic, the East Siberian Sea, the Laptev, Kara, Barents, East Greenland, and Bering Seas, and the Sea of Okhotsk. 
The annual cycle of moisture contribution shows maximum values for late summer and early fall when the sea ice is at a minimum. Despite high values of total moisture contribution during summer, its distribution is mainly over the Arctic itself, having little contribution over the continental areas of Alaska and Eastern Asia.

The location of the main sinks for Arctic moisture is a first step in the analysis of the Arctic moisture transport and forms part of the investigation of the possible implications of changes in the Arctic in respect of the global climate. Of particular interest may be the analysis of the changes in Arctic moisture contribution over the Northern Hemisphere associated with maximum and minimum sea ice extents, which could form the basis of future work.

\section{Acknowledgements}

The authors acknowledge funding by the Spanish government within the EVOCAR (CGL2015-65141-R) project, which is also funded by FEDER (European Regional Development Fund). Raquel Nieto was also supported by the Brazilian government through a CNPq grant 314734/2014-7.

\section{References}

Boisvert, L.N., Wu, D.L., Shie, C.L. 2015. Increasing evaporation amounts seen in the Arctic between 2003 and 2013 from AIRS data. Journal of Geophysical Research: Atmospheres 120 (14), 6865-6881. https://doi.org/10.1002/2015JD023258.

Bowman, K.P., Lin, J.C., Stohl, A., Draxler, R., Konopka, P., Andrews, A., Brunner, D. 2013. Input Data Requirements for Lagrangian Trajectory Models. Bulletin of the American Meteorological Society 94, 1051-1058. https://doi.org/10.1175/BAMS-D-12-00076.1.

Castillo, R., Nieto, R., Drumond, A., Gimeno, L. 2014. Estimating the temporal domain when the discount of the net evaporation term affects the resulting net precipitation pattern in the moisture budget using a 3-D Lagrangian approach. PLoS ONE 9 (6). https://doi.org/10.1371/ journal.pone.0099046.

Cavalieri, D.J., Parkinson, C.L. 2012. Arctic sea ice variability and trends, 1979-2010. The Cryosphere 6, 881-889. https://doi.org/10.5194/tc-6-881-2012.

Cohen, J., Screen, J.A., Furtado, J.C., Barlow, M., Whittleston, D., Coumou, D., Francis, J., Dethloff, K., Entekhabi, D., Overland, J., Jones, J. 2014. Recent Arctic amplification and extreme mid-latitude weather. Nature Geoscience 7, 627-637. https://doi.org/10.1038/ ngeo2234.

Comiso, J.C., Hall, D.K. 2014. Climate trends in the Arctic as observed from space. WIREs Climate Change 5, 389-409. https://doi.org/10.1002/wcc.277.

Comiso, J.C., Parkinson, C.L., Gersten, R., Stock, L. 2008. Accelerated decline in the Arctic sea ice cover. Geophysical Research Letters 35, L01703. https://doi.org/10.1029/2007GL031972.

Dee, D.P., Uppala, S.M., Simmons, A.J., Berrisford, P., Poli, P., Kobayashi, S., Andrae, U., Balmaseda, M.A., Balsamo, G., Bauer, P., Bechtold, P., Beljaars, A.C.M., van de Berg, L., Bidlot, J., Bormann, N., Delsol, C., Dragani, R., Fuentes, M., Geer, A.J., Haimberger, L., Healy, S.B., Hersbach, H., Hólm, E.V., Isaksen, L., Kallberg, P., Köhler, M., Matricardi, M., McNally, A.P., Monge-Sanz, B.M., Morcrette, J.J., Park, B.K, Peubey, C., de Rosnay, P., Tavolato, C., Thépaut, J.N., Vitart, F. 2011. The ERA-Interim reanalysis: configuration and performance of the data assimilation system. Quarterly Journal of the Royal Meteorological Society 137, 553-597. https://doi.org/10.1002/qj.828. 
Fetterer, F., Knowles, K., Meier, W., Savoie, M. 2016, updated daily. Sea Ice Index, Version 2. Boulder,Colorado USA. NSIDC: National Snow and Ice Data Center. https://doi.org/10.7265/ N5736NV7.

Gimeno, L., Stohl, A., Trigo, R.M., Domínguez, F., Yoshimura, K., Yu, L., Drumond, A., DuránQuesada, A.M., Nieto, R. 2012. Oceanic and terrestrial sources of continental precipitation. Reviews of Geophysics 50, RG4003. https://doi.org/10.1029/2012RG000389.

Gimeno, L., Nieto, R., Drumond, A., Castillo, R., Trigo, R.M. 2013. Influence of the intensification of the major oceanic moisture sources on continental precipitation. Geophysical Research Letters 40, 1443-1450. https://doi.org/10.1002/grl.50338.

Groves,D.G.,Francis, J.A. 2002. Moisture budget of the Arctic atmosphere from TOVS satellite data. Journal of Geophysical Research 107 (D19), 4391. https://doi.org/10.1029/2001JD001191.

Holland, M.M., Bitz, C.M., Tremblay, B. 2006. Future abrupt reductions in the summer Arctic sea ice. Geophysical Research Letters 33, L23503. https://doi.org/10.1029/2006GL028024.

Koerner, R., Russell, R.D. 1979. Delta-O-18 variations in snow on the Devon Island Ice Cap, Northwest-Territories, Canada. Canadian Journal of Earth Sciences 16 (7), 1419-1427. https://doi.org/10.1139/e79-126.

Liu, J.P., Curry, J.A., Wang, H.J., Song, M.R., Horton, R.M. 2012. Impact of declining Arctic sea ice on winter snowfall. Proceedings of the National Academy of Sciences USA 109, 40744079. https://doi.org/10.7312/li--16274-011.

Meier, W.N., Fetterer, F., Savoie, M., Mallory, S., Duerr, R., Stroeve, J. 2013. NOAA/NSIDC Climate Data Record of Passive Microwave Sea Ice Concentration. 2 ed. N. S. a. I. D. Center, Ed., NSIDC.

Nieto, R., Gimeno, L., Gallego, D., Trigo, R. 2007. Contributions to the moisture budget of airmasses over Iceland. Meteorologische Zeitschrift 16 (1), 37-44. https://doi.org/10.1127/09412948/2007/0176.

Numagati, A. 1999. Origin and recycling processes of precipitation water over the Eurasian continent: Experiments using an atmospheric general circulation model. Journal of Geophysical Research 104, 1957-1972. https://doi.org/10.1029/1998JD200026.

Overlan, J.E., Wang, M. 2010. Large-scale atmospheric circulation changes are associated with the recent loss of Arctic sea ice. Tellus A 62, 1-9. https://doi.org/10.1111/j.16000870.2009.00421.x.

Overland, J.E., Wang, M., Walsh, J.E., Stroeve, J.C. 2014. Future Arctic climate changes: Adaptation and mitigation time scales. Earth's Future 2, 68-74. https://doi. org/10.1002/2013EF000162.

Park, H, Walsh, J.E, Kim, Y, Nakai, T., Ohata T. 2013. The role of declining Arctic sea ice in recent decreasing terrestrial Arctic snow depths. Polar Science 7, 174-187.https://doi.org/10.1016/j. polar.2012.10.002.

Parkinson, C.L., Di Girolamo, N.E. 2016. New visualizations highlight new information on the contrasting Arctic and Antarctic sea-ice trends since the late 1970s. Remote Sensing of Environment 183, 198-204. https://doi.org/10.1016/j.rse.2016.05.020.

Polyakov, I.V., Walsh, J.E., Kwok, R. 2012. Recent Changes of Arctic Multiyear Sea Ice Coverage and the Likely Causes. Bulletin of the American Meteorological Society 93, 145151. https://doi.org/10.1175/BAMS-D-11-00070.1.

Scarchilli, C., Frezzotti, M., Ruti, P.M. 2011. Snow precipitation at four ice core sites in East Antarctica: provenance, seasonality and blocking factors. Climate Dynamics 37, 2107-2125. https://doi.org/10.1007/s00382-010-0946-4.

Schlosser, E., Oerter, H., Masson-Delmotte, V., Reijmer, C.H. 2008. Atmospheric influence on the deuterium excess signal in polar firn: implications for ice-core interpretation. Journal of Glaciology 54 (184), 117-124. https://doi.org/10.3189/002214308784408991. 
Serreze, M.C., Barrett, A.P., Slater, A.G., Woodgate, R.A., Aagaard, K., Lammers, R.B., Steele, M., Moritz, R., Meredith, M., Lee, C.M. 2006. The large-scale freshwater cycle of the Arctic. Journal of Geophysical Research 111, C11010. https://doi. org/10.1029/2005JC003424.

Sodemann, H., Schwierz, C., Wernli, H. 2008. Interannual variability of Greenland winter precipitation sources: Lagrangian moisture diagnostic and North Atlantic Oscillation influence. Journal of Geophysical Research 113, D03107. https://doi. org/10.1029/2007JD008503.

Stohl, A., James, P. 2004. A Lagrangian Analysis of the Atmospheric Branch of the Global Water Cycle. Part I: Method Description, Validation, and Demonstration for the August 2002 Flooding in Central Europe. Journal of Hydrometeorology 5, 656-678. https://doi. org/10.1175/1525-7541(2004)005<0656:ALAOTA>2.0.CO;2.

Stohl, A., James, P.A. 2005. A Lagrangian Analysis of the Atmospheric Branch of the Global Water Cycle. Part II: Moisture Transports between Earth's Ocean Basins and River Catchments. Journal of Hydrometeorology 6, 961-984. https://doi.org/10.1175/ JHM470.1.

Stohl, A., Forster, C., Sodemann, H. 2008. Remote sources of water vapor forming precipitation on the Norwegian west coast at $60 \mathrm{~N}-\mathrm{A}$ tale of hurricanes and an atmospheric river. Journal of Geophysical Research Atmospheres 113, D05102. https:// doi.org/10.1029/2007JD009006.

Stohl, A., Haimberger, L., Scheele, M.P., Wernli, H. 2001. An intercomparison of results from three trajectory models. Meteorological Applications 8 (2), 127-135. https://doi. org/10.1017/S1350482701002018.

Stroeve, J.C., Markus, T., Boisvert, L., Miller, J., Barrett, A. 2014. Changes in Arctic melt season and implications for sea ice loss. Geophysical Research Letters 41, 1216-1225. https://doi.org/10.1002/2013GL058951.

Stroeve, J.C., Mioduszewski, J.R., Rennermalm, A., Boisvert, L.N., Tedesco, M., Robinson, D. 2017. Investigating the local scale influence of sea ice on Greenland surface melt. The Cryosphere Discussions. https://doi.org/10.5194/tc-2017-65.

Vázquez, M., Nieto, R., Drumond, A., Gimeno, L. 2016. Moisture transport into the Arctic: Source-receptor relationships and the roles of atmospheric circulation and evaporation. Journal of Geophysical Research: Atmospheres 121, 13,493-13,509. https://doi. org/10.1002/2016JD025400.

Vihma, T. 2014. Effects of Arctic Sea Ice Decline on Weather and Climate: A Review. Surveys in Geophysics 35, 1175. https://doi.org/10.1007/s10712-014-9284-0.

Vihma, T., Screen, J., Tjernström, M., Newton, B., Zhang, X., Popova, V., Deser, C., Holland, M., Prowse, T. 2016. The atmospheric role in the Arctic water cycle: A review on processes, past and future changes, and their impacts. Journal of Geophysical Research: Biogeosciences 121, 586-620. https://doi.org/10.1002/2015JG003132.

Wang, M., Overland, J.E. 2009. A sea ice free summer Arctic within 30 years? Geophysical Research Letters 36, L07502. https://doi.org/10.1029/2009GL037820.

Wegmann, M., Orsolini, Y., Vázquez, M., Gimeno, L., Nieto, R., Bulygina, O., Jaiser, R., Handorf, D., Rinke, A., Dethloff, K., Sterin, A., Brönnimann, S. 2015. Arctic moisture source for Eurasian snow cover variation in autumn. Environmental Research Letters 10, 054015. https://doi.org/10.1088/1748-9326/10/5/054015.

See Supplementary Materials at http://publicaciones.unirioja.es/revistas/cig2018/Vazquez_supplmat.pdf 